\title{
The canonical correlation between perceptions of parents and psychological and social well-being in students
}

\author{
Farhad Tanhaye Reshvanloo $^{1}$, Talieh Saeidi Rezvani ${ }^{2}$, Hossein Kareshki ${ }^{3}$ \\ 1-Ph.D student in Educational Psychology, Department of Counseling and Educational psychology, Faculty of \\ Educational sciences and psychology, Ferdowsi University of Mashhad, Mashhad, Iran (Corresponding Author). \\ E-mail: farhadtanhay@um.ac.ir \\ 2- Ph.D student in Educational Psychology, Department of Counseling and Educational psychology, Faculty of \\ Educational sciences and psychology, Ferdowsi University of Mashhad, Mashhad, Iran. \\ 3- Associate Professor, Department of Counseling and Educational psychology, Faculty of Educational sciences and \\ psychology, Ferdowsi University of Mashhad, Mashhad, Iran.
}

Received: 05/07/2019 Accepted: 09/10/2019

\begin{abstract}
Introduction: Health is not merely the absence of illness and it includes psychological and social well-being. Psychological and social well-being seems to be influenced by parental parenting styles.

Aim: The purpose of this study was to investigate the canonical correlation between parental perceptions with psychological and social well-being of students.

Method: The design of this study was descriptive-correlation and statistical community consisted of undergraduate students of Payame Noor University of Mashhad in fall semester of 2018. The sample size was 235 students was selected using multistage random sampling and completed Perceptions of Parents Styles (Robbins, 1994), psychological well-being (Ryff, 1989) and social well-being (Keyes, 1998) questionnaires. Data were analyzed by Pearson Correlation Coefficient and Canonical Correlation and SPSS.25 software.

Results: The results showed that there is a significant relationship between parenting styles and psychological and social well-being. The common variance of parenting styles and psychological and social well-being was $34 \%$.
\end{abstract}

Conclusion: Hence, it seems that warm and friendly behavior along with parents' affection toward children can have sustainable impacts on children's mental health.

Keywords: Well-being, Parenting, Students

\footnotetext{
How to cite this article : Tanhaye Reshvanloo F, Saeidi Rezvani T, Kareshki H. The canonical correlation between perceptions of parents and psychological and social well-being in students. Shenakht Journal of Psychology and Psychiatry. 2019; 6 (5): 141-155 .URL: http://shenakht.muk.ac.ir/article-1-685-fa.pdf

Copyright () 2018 the Author (s). Published by Kurdistan University of Medical Sciences. This is an open access article distributed under the terms of the Creative Commons Attribution-Non Commercial License 4.0 (CCBY-NC), where it is permissible to download, share, remix, transform, and buildup the work provided it is properly cited. The work cannot be used commercially without permission from the journal.
} 


\section{همبستكى كانونى ادر اكات والدينى با بهزيستى روانشناختى و اجتماعى در دانشجويان}

\section{فرهاد تنهاى رشوانلو'، طليعه سعيدى رضوانى '، حسين كارشكى}

ا.دانشجوى دكترى روانشناسى تربيتى، كروه روانشناسى مشاوره و تربيتى، دانشكده علوم تربيتى و روانشناسى، دانشكاه فردوسى مشهد، مشهد، ايران (مولف إنفي مسئول). ايميل: farhadtanhay@um.ac.ir

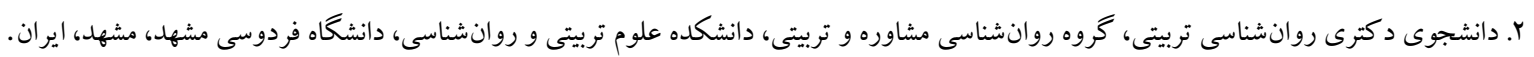

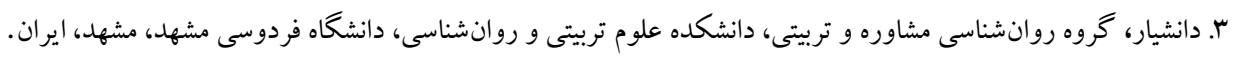

مقدمه: سلامت صرفاً به منزله غياب بيمارى نبوده و بهزيستى روانى و اجتماعى را نيز در بر مى گيرد. به نظر مى رسد بهزيستى

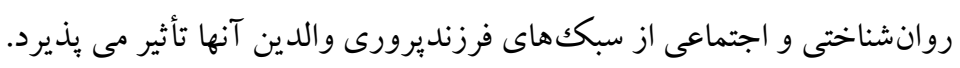

هدف: يزوهش حاضر با هدف بررسى همبستخى كانونى ادراكات والدينى با بهزيستى روانشناختى و اجتماعى در دانشجويان انجام

روش: طرح يزوهش حاضر از نوع توصيفى -همبستگى بود. جامعه آمارى آن را دانشجويان دوره كارشناسى دانشگاه ييام نور مشهد در

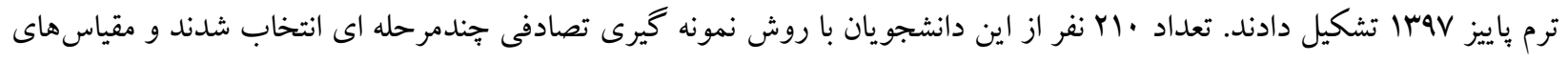

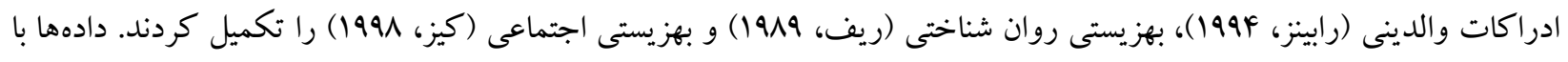

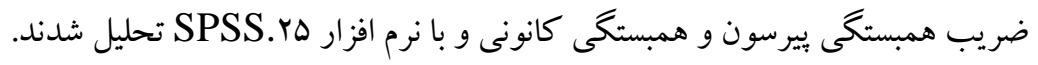

يافتها: نتايج نشان داد كه ميان ادراكات والدينى و بهزيستى روانشناختى و اجتماعى رابطه معنادارى وجود دارد. واريانس مشترك

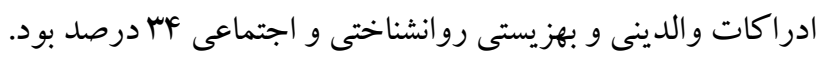

نتيجه حيرى: بر اين اساس به نظر مىرسد رفتار گرم و صميمانه و توأم با محبت بدر و مادر نسبت به فرزندان مىتواند تأثيرات نسبتاً

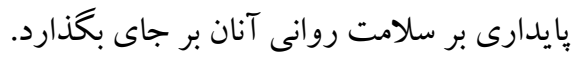
كليد وازهها: بهزيستى، فرزنديرورى، دانشجويان 


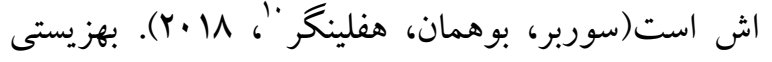
روانشناختى از شخصيت و حمايت اجتماعى(فرجى، مقتدر و و اسدى فجره، روانشناختى و سرسختى روانشناختى(اصغرى ابراهيم

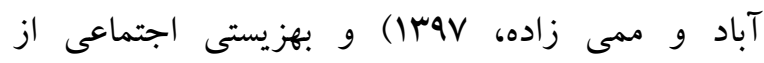
شخصيت(صفارى نيا، تدريس تبريزى، محتشمى و حسن

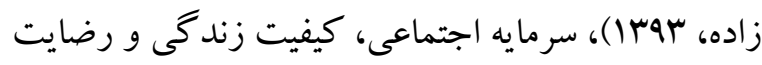

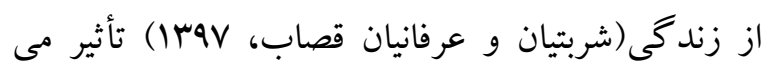

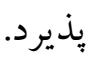

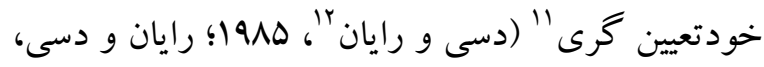
نظ (Y.IV ارتباط با تبعات مختلف تحصيلى، انگيزشى و سلامت مورد بررسى قرار داده و بهزيستى و سلامت را منوط به ارضاى نيازهاى بنيادين روانشناختى مىداند. اين نيازها

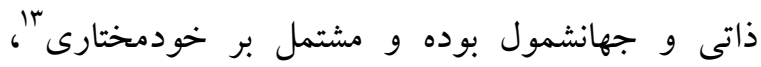

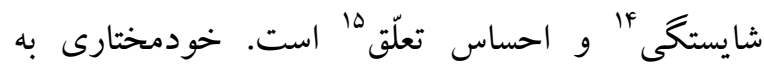
انتخاب آزادانه اعمال و خواسته ها، شايستگى به احساس

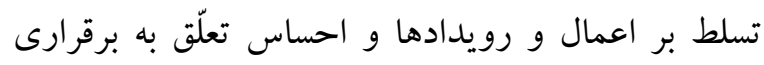
رابطه با افراد مهم زندگى و برخوردارى از حمايت آنان،

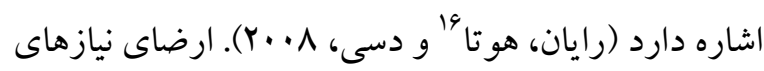
بنيادين روانى با بهزيستى روانى (كورديرو، بايزائو، لنز،

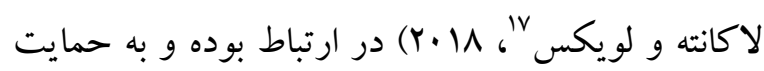
محيط نياز دارد و از اين طريق است كه افراد مىتواند به سطوح بالاى بهزيستى و سلامت دست يابند(رايان،

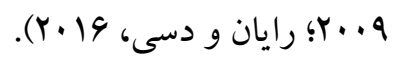

${ }^{10}$ - Thurber, Bohmann, \& Heflinger

11- Self-determination

12 - Deci \& Ryan

13 - Autonomy

${ }^{14}$ - Competence

15 - Relatedness

16. Huta

${ }^{17}$ - Cordeiro Paixão, Lens, Lacante, \& Luyckx
مقدمه به رغم تأكيد سازمان بهداشت جهانى بر جندبعدى بودن سلامت و در نظر خرفتن سلامت به عنوان (احالتى از بهزيستى كامل جسمى، ذهنى و اجتماعى و نه صرفاً فقدان بيمارى)، غالباً متخصصان به جاى توجه به جنبه هاى مثبت سلامت، بيشتر درگير مهار و درمان بيمارىهاى روانى بودند. دليل اين امر را شايد بتوان رشد يافته تر بودن حوزه آسيبشناسى روانى در ادبيات روانشناختى در مقايسه با مفهوم سازىهاى مثبت سلامت روانى دانست(كىيز'،

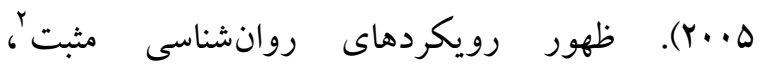
يثزوهشگران حوزه سلامت را بر آن داشت تا رويكرد نظرى و يثزوهشى متفاوتى را بر ززيده و سلامت روانى را معادل كاركرد مثبت روانشناختى تلقى و در قالب

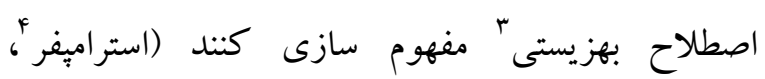

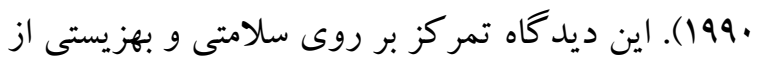
جنبه مثبت و نيز توضيح و تبيين ماهيت روانشناختى بهزيستى را مطمح نظر قرار داده است (ريف و سينگرها؛ 1991). تعاريف روانشناسى مثبت از بهزيستى، عموماً شامل تعادل در حالات، خلق مثبت و رضايت از زندگى، جندبعدى بودن، بهينه سازى شخصى و رفتارهاى اجتماع

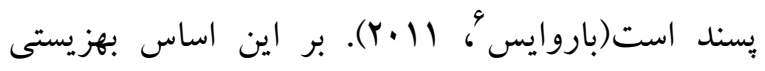

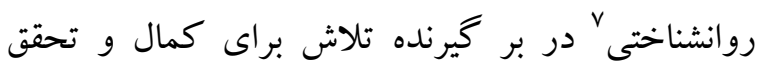

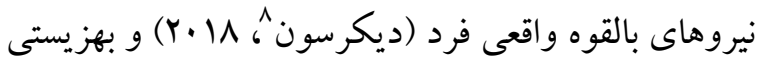

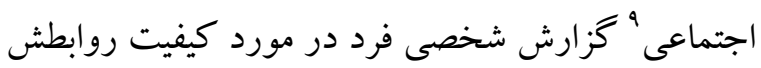
با افراد ديخر، جايى كه در آن زندگى مى كند و جامعه

\footnotetext{
1 - Keyes

${ }^{2}$ - Positive Psychology

3 - Well-being

${ }^{4}$ - Strumpfer

5 - Ryff, \& Singer

${ }^{6}$ - Barwais

7- Psychological Well-being

${ }^{8}$ - Dickerson

'- Social Well-being
} 
(تنهاى رشوانلو و حجازى، •وra؛ تنهاى رشوانلو و طالع

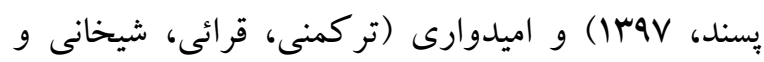

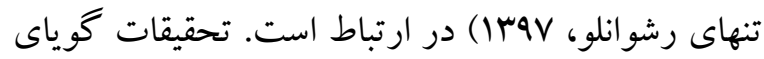
آن است كه تأثير گذارى مادر و بِدر بر بهزيستى فرزندان

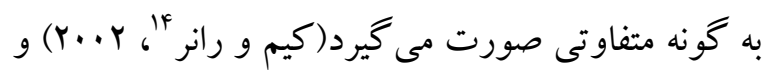
از سوى ديخر اثرات حمايت از خودمختارى و رفتار گرم و يذيرنده والدين در ساليان يس از كودكى و نوجوانى

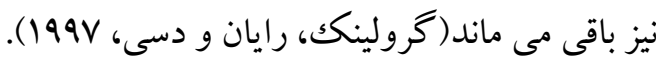
بهزيستى و سلامت روانى دانشجويان به عنوان قشرى تأثير گذار، كه با تجارب مختلف در جامعه، دانشگاه و خانواده مواجه هستند، تحت تأثير عوامل مختلف قرار مى كيرد. يكى از اين عوامل اثر گذار، شيوه رفتار و تعامل با والدين است. در بررسى ويشينه يُزوهشى در داخل كشور، مطالعه اى كه روابط ميان سبك هاى فرزنديرورى مبتنى بر نظريه خودتعيين گرى با بهزيستى روانشناختى و

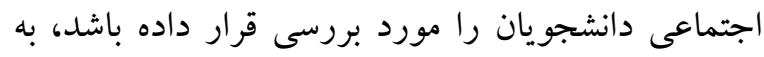
دست نيامد. در ساير مطالعات نيز جامعه آمارى

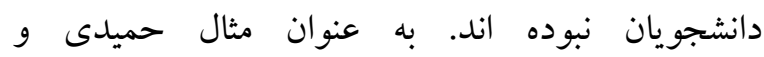

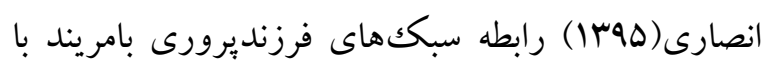
بهزيستى روانشناختى را در دانش آموزان مورد بررسى قرار داده و رابطه مثبت و معنادارى ميان سبك روكى فرزنديرورى مقتدرانه و بهزيستى روانشناختى به دست آوردند. بر اين اساس و با توجه به اهميت بهزيستى روانشناختى و اجتماعى در دانشجويان و نيز تأثيريذيرى آن از ادراكات والدينى، هدف از يزوهش حاضر بررسى رابطه ادراكات والدينى با بهزيستى روانشناختى و و اجتماعى در دانشجويان با تحليل همبستگى كانونى بود.

\footnotetext{
14- Kim \& Rohner
}

به نظر مىرسد كه والدين اولين افرادى هستند كه مى توانند بر ارضاى نيازهاى روانشناختى فرزندان خود

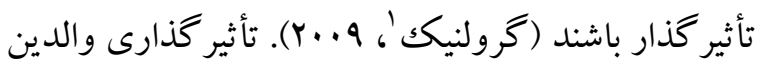
در جارجوب نظريه خودتعيين گرى، در قالب سبككهاى فرزنديرورى مورد بحث قرار مى گيرد. در گيرى ' يكى از سبككهاى فرزنديرورى مورد بحث در اين نظريه است و به توجه مثبت و فرصتهايى كه والدين به فرزندان خود

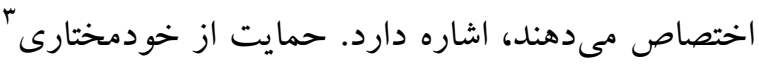
به درجهاى كه والدين براى فعاليتهاى فرزندان خود ارزش قائل شده و به آنان حق انتخاب و شركت در

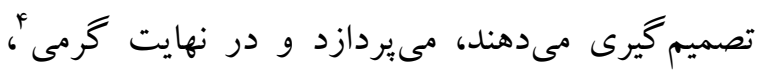
ميزانى از بِاسخگ بودن، حساسيت و صميمى بودن

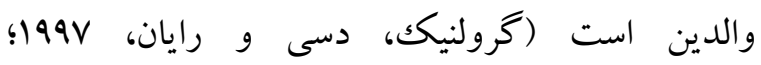

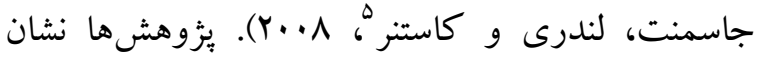
مىدهد كه سبكهاى فرزنديرورى با بهزيستى و و

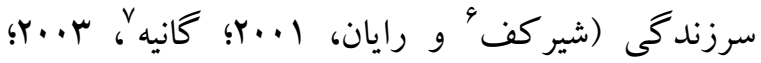

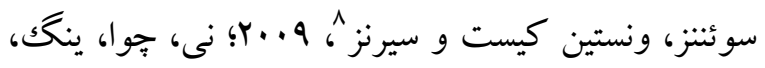

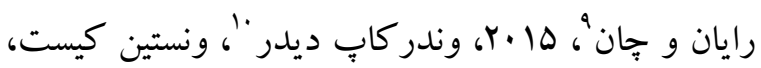

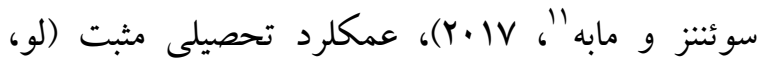

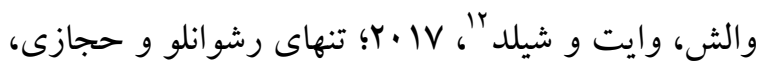

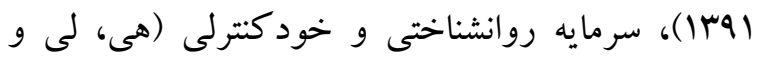

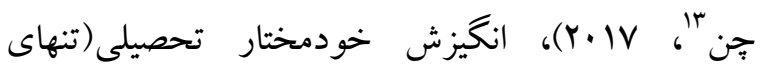

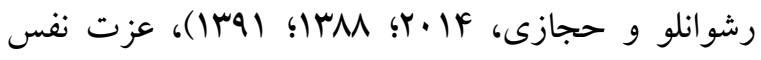

\footnotetext{
1- Grolnick

2- Involvement

3 - Autonomy support

4- Warmth

5 - Joussemet, Landry, \& Koestner,

${ }^{6}$ - Chirkov

7. Gagné

8 - Soenens, Vansteenkiste, \& Sierens

9 - Nie, Chua, Yeung, Ryan, \& Chan

${ }^{10}$ - Van der Kaap-Deeder

${ }^{11}$ - Mabbe

${ }^{12}$ - Lu, Walsh, White, \& Shield

${ }^{13}$ - He, Liu, \& Chen
} 
يرسشنامهاى ناقص، داده هاى مربوط به ذبr نفر تحليل شد.

ابزار كردآورى دادهها در بيزوهش حاضر از طريق برسشنامه هاى ذيل صورت گرفت: مقياس ادراكات والدينى"(POPS): اين مقياس توسط رابينز (1994) و بر اساس نظريه خود تعيين گرى تدوين

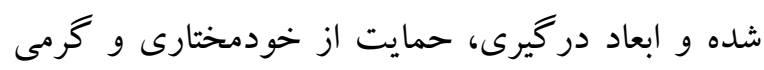
مادر و يدر را با FY FY عبارت مىسنجد. عبارت ها در دو

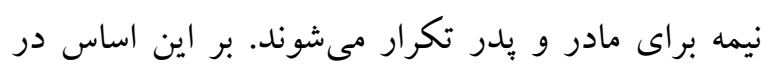

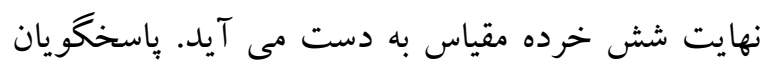
بايد به عبارتها در طيف V درجهاى ليكرت از در مورد من اصلاً درست نيست(1) تا در مورد من كاملاً درست است(V) ياسخ دهند. نمرات بالاتر در هر زير مقياس نشان

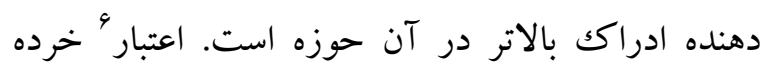
مقياس هاى حمايت از خودمختارى مادر - بدر به ترتيب در مطالعه اصلى •^/ · و זم/ · بدست آمده است (رابينز،

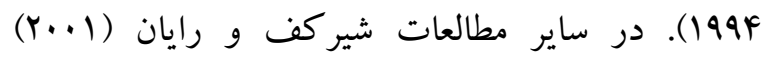
ضرايب آلفاى هA/· تا צو/· را براى حمايت از خودمختارى مادر و بدر گزارش كردهاند. تنهاى رشوانلو

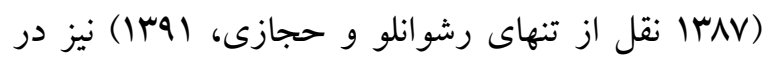
مطالعهاى بس از ترجمه و تأييد روايى صورى به بررسى

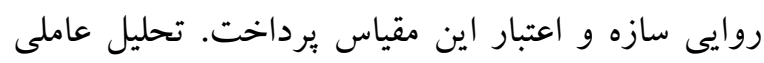
F. اكتشافى با جرخش واريماكس نشان داد كه فقط عبارت با نسخه اصلى هماهنگك بوده و زير شش عامل بار

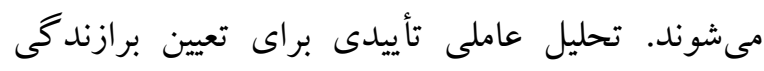
ساختار جديد به اجرا در آمد و ساختار جديد به تأييد

4- Perceptions of Parents Scale(POPS)

5 - Robbins

${ }^{6}$ - Reliability
طرح يثوهش حاضر از نوع توصيفى - همبستكى بوده و از تحليل همبستكى كانونى براى بررسى روابط ميان دو مجموعه از متغير بيش بين (ادراكات والدينى) و ملاكك (بهزيستى روانشناختى و اجتماعى) استفاده مى كند. اين روش شناسى امكان بررسى روابط ميان جند متغير بيش بين با جندمتغير ملاكك را به طور همزمان فراهم مى آورد

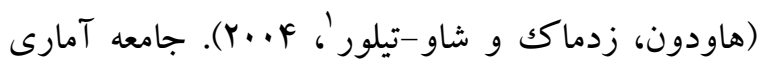
يثزوهش حاضر را دانشجويان دوره كارشناسى دانشگاه

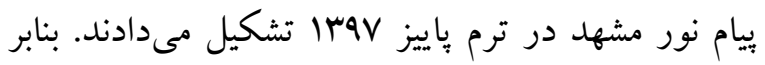

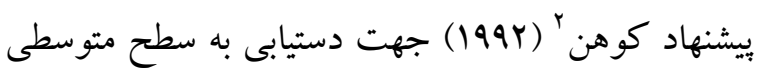
از اندازه اثر حداقل ل111 نفر نمونه لازم است. اما

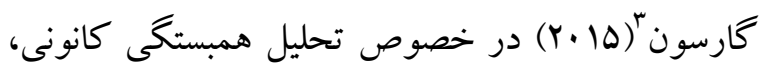

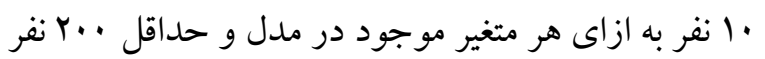
نمونه را بيشنهاد مى كند. با توجه به احتمال ريزش نفرات

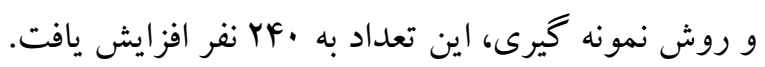
نمونه گيرى با روش تصادفى جندمرحله اي صورت كرفت. بدين ترتيب كه در ابتدا جهار رشته تحصيلى از ميان گروه هاى تحصيلى موجود (علوم انسانى، علوم بايه و فنى و مهندسى) به صورت تصادفى انتخاب شدند. در هر رشته تحصيلى نيز يكك ورودى به تصادف انتخاب و يرسشنامه در ميان ·r نفر از دانشجويان توزيع كرديد. ملاكك ورود به بثزوهش اشتغال به تحصيل در دانشگاه بيام

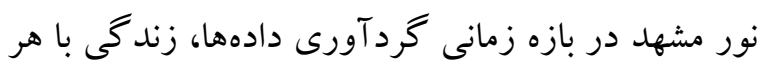
دو والد و نيز برخوردارى از سلامت جسمانى و روانى بود. يرسشنامه دانشجويانى كه تنها با يكى از والدين

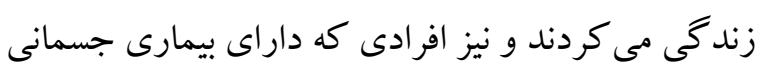
خاص يا سابقه دريافت درمان روانيزشكى بودند، از

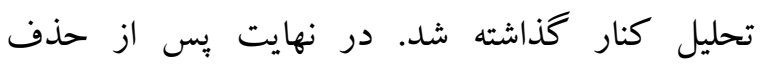

\footnotetext{
1- Hardoon, Szedmak, \& Shawe-Taylor

2- Cohen

3. Garson
} 
دركك يذيرى اجتماعى را مىسنجد. ياسخكويى به اين مقياس در طيف V درجه اي از كاملاً مخالف (1) تا كاملاً

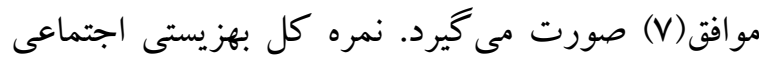
با جمع بستن تمامى عبارتها، يس از معكوس كردن نمرات برخى از عبارات، به دست آمده و به معناى بهزيستى اجتماعى بالاتر است. كى يز (ه. ㄷ) ضريب اعتبار |1/· را براى كل مقياس گزارش كرد. جوشن لو،

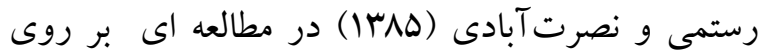
دانشجويان ايرانى ساختارى مشابه نسخه اصلى بدست آورده و ميزان آلفاى كرونباخ زير مقياسهاى بهزيستى

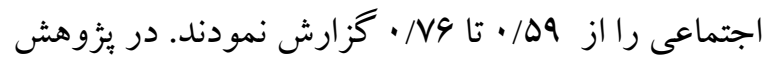
حاضر ضريب آلفاى كرونباخ rی/· براى كل مقياس به دست آمد. گردآورى داده ها به صورت گروهى و توسط نويسند كان صورت گرفت. يِيش از اجرا، در خصوص اهداف طرح توضيحاتى به شركت كنند كان داده شده و رضايت شفاهى آنان جهت تكميل برسشنامها اخذ كرديد. شركت در بزّوهش كاملاً داوطلبانه بوده و تمامى برسشنامهها بى نام بودند. به شركت كنند كان اطمينان داده شد كه اطلاعات آنان محرمانه بوده و تنها در اختيار يثزو هشخر ان مىباشد. تحليل دادهها با استفاده از روش تحليل همبستخى كانونى

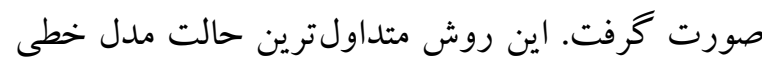
عمومى است كه با استفاده از روشهاى آمارى جندمتغيرى رابطه ميان دو مجموعه از متغيرهاى جند كانه را مورد بررسى قرار مىدهد. اين تحليل تركيب خطى

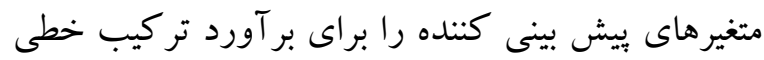
متغيرهاى بيش بينى شونده به كار مىبرد(هاودون و
رسيد. اعتبار مقياس نيز با محاسبه آلفاى كرونباخ مورد بررسى قرار گرفت و ضرايب Ar/ • تا سه/ • براى خردهمقياسها و rه/ • براى كل مقياس بدست آمد. اعتبار اين مقياس در مطالعات ديخرى نيز به تأييد رسيده است (تنهاى رشوانلو و حجازى، •وسا، تنهاى رشوانلو و طالع

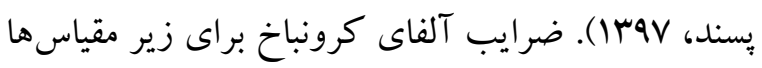

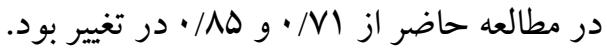
فرم كوتاه مقياس بهزيستى روانشناختى': اين مقياس توسط ريف ب (1919) تدوين گرديد. اين مقياس مشتمل بر 11 ماده بوده و شش بعد بهزيستى روان شناختى شامل خود ييروى، سلطه بر محيط، رشد شخصى، روابط مثبت با ديخران، هدفمندى در زندگى و يذيرش خود را در طيف ليكرت V درجه اي از ( كاملاً مخالف) تا هاملاً موافق) مى سنجد. نمره كل مقياس با جمع بستن نمرات در

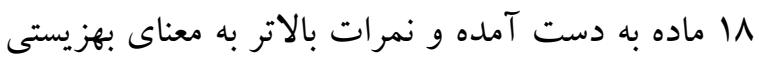
روانشناختى بالاتر است و بالعكس. اعتبار و روايى اين مقياس در مطالعات متعددى به تأييد رسيده

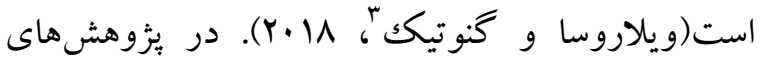
داخلى ضرايب آلفاى كرونباخ براى خرده مقياسها از سא/· تا •19/ كزارش شده است (جوشن لو، رستمى و نصرت آبادى، هیץ|). در مطالعه حاضر از نمره كل مقياس استفاده شده و آلفاى كرونباخ آن برابر با لول• به

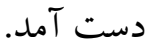

فرم كوتاه مقياس بهزيستى اجتماعى"! اين مقياس توسط

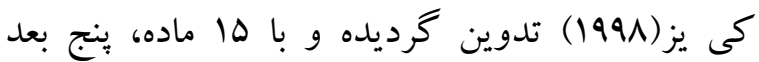

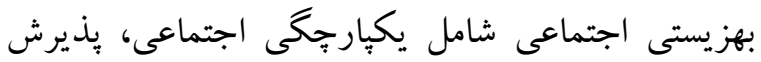

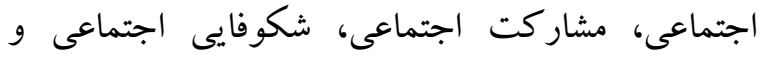

\footnotetext{
1- Psychological well-being scale-short form

2- Ryff

3. Villarosa, \& Ganotice

4- Social well-being scale-short form
} 
بررسى قرار گرفت (ميرز، كامست و گوارينو، 19.r).

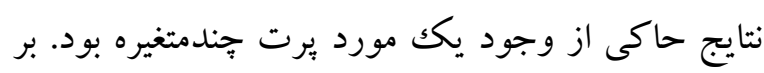
اين اساس به حذف اين شركت كننده برداخته شد و

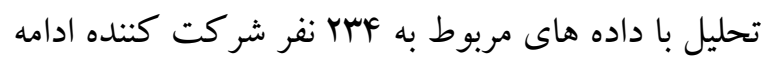
يافت. شاخص اصلاح شده در مورد تمامى شركت

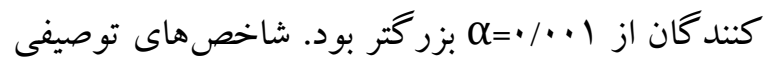
و ضرايب همبستخى متغيرهاى بزوهشى در جدول آورده شده است.
همكاران، Y........ در اين تحليل دو تابع كانونى' تشكيل مى شود كه يكى مربوط به متغيرهاى ملاكك و ديخرى مربوط به متغيرهاى يُش بين است. وزنهاى كانونى 'ّدر

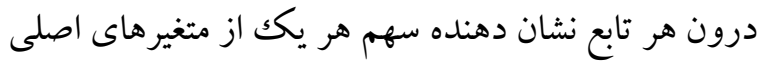
در ضرايب همبستخى كانونى بوده و همانند ضرايب بتا در رگرسيون هستند. بارهاى كانونى “ّ همبستگى ساده ميان متغيرهاى اصلى و تابع كانونى متناظر آنهاست(يوسفى، باقريان و شجاعى، سهبا). تجزيه و تحليل داده با محاسبه شاخصهاى توصيفى، ضريب همبستگى بيرسون و و

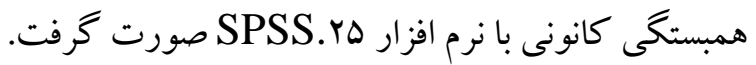

\section{يافتهها}

توصيف جمعيت شناختى نشان داد كه در كل نمونه درصد را مردان تشكيل مىدادند؛ ميانگين و انحراف معيار

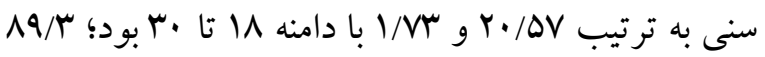
درصد دانشجويان مجرد بودند؛ A/سم درصد در كروه علوم انسانى، س/بس درصد در گروه علوم يايه و درصد در گروه فنى و مهندسى مشغول به تحصيل بودند. بيش از تحليل به غربالخرى دادهها برداخته شده و مقادير دور افتاده شناسايى و اصلاح شدند. برتهاى تكك متغيره با نمودار باكس "مورد بررسى قرار گرفتند. نتايج نشان داد كه هرت تكك متغيره اى وجود ندارد. شناسايى برتهاى

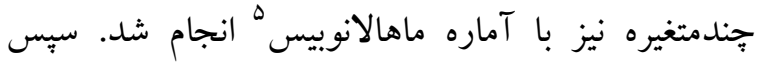
فواصل مورد نظر بر اساس درجات آزادى (تعداد متغيرها كه در اينجا شش متغير بيش بين موجود در مدل بود) در

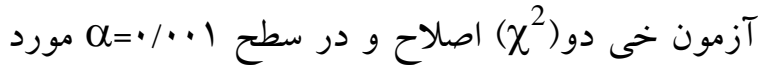

1. Canonical Function

2- Weight Canonical

3 - Canonical Loading

${ }^{4}$ - Box plot

5 - Mahalanobis 


\begin{tabular}{|c|c|c|c|c|c|c|c|c|}
\hline \multirow[t]{8}{*}{$\Lambda$} & r & 4 & $\Delta$ & f & $r$ & $r$ & 1 & \\
\hline & & & & & & & 1 & ا. درگيرى مادر \\
\hline & & & & & & 1 & $\cdot / r 4^{* * * * *}$ & r. حمايت مادر از خودمختارى \\
\hline & & & & & 1 & $\cdot / \Delta \Delta^{* * * *}$ & $\cdot / Y I^{* * * *}$ & 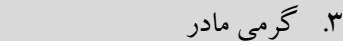 \\
\hline & & & & 1 & $\cdot / / V^{* * * *}$ & $\cdot / / V^{*}$ & $\cdot / \mu \cdot{ }^{* * * * *}$ & F أ. در گيرى بدر \\
\hline & & & 1 & $\cdot / 4^{* * * *}$ & $\cdot 119^{*}$ & $\cdot / r \Delta^{* * * *}$ & $\cdot / r^{* * * *}$ & ه. حمايت يدر از خودمختارى \\
\hline & & 1 & $\cdot / \Delta 9^{* * * *}$ & $\cdot / r 9^{* * * w^{*}}$ & $\cdot / r \Delta^{* * * * *}$ & $\cdot / Y r^{* * * * *}$ & $\cdot / 19^{*}$ & 9. كرمى بدر \\
\hline & 1 & • & $\cdot / r \Delta^{* * * *}$ & $\cdot|f|^{* * * *}$ & $\cdot / \mu Y^{* * * * *}$ & $\cdot / \varphi^{* * * *}$ & $\cdot / \pi r^{* * * *}$ & V. . بهزيستى روانشناختى \\
\hline 1 & $\cdot / 4 q^{* * * *}$ & $\cdot / Y f^{* * * * *}$ &.$/ 10^{*}$ & $\cdot / I^{* * * * *}$ & $\cdot / r f^{* * * *}$ & $\cdot / 19^{* * * *}$ & $\cdot / r f^{* * * *}$ & ᄉ بهزيستى اجتماعى \\
\hline $99 / 00$ & $M / r V$ & $\mathrm{MI/VF}$ & $r V / r I$ & $\mid \mathrm{V} / \mathrm{r} \Lambda$ & Tr/Td & rV/rt & $11 / 1 V$ & ميانكين \\
\hline $1 \cdot / \mu F$ & $1 \cdot / \Delta V$ & $\Lambda / \cdot \Lambda$ & $9 / 1$. & $r / 9 r$ & V/r & $9 / 99$ & $r / \cdot r$ & انحر اف استاندارد \\
\hline.$/ 11$ & $-\cdot / \cdot r$ & $-\cdot / V Y$ & -.1 .9 &.$/ 1 r$ & -.199 & $-\cdot / \mu F$ &.$- / 19$ & كجى \\
\hline$\cdot|A|$ & $-\cdot / T F$ & $-\cdot / I V$ & $-\cdot / 10$ & $-\cdot / \Delta \Lambda$ &.$- / 19$ & $-\cdot / F F$ & $-\cdot / \mathrm{V} \Lambda$ & كشيدگى \\
\hline
\end{tabular}

عدم همخطى متغيرهاى بيش بين مدل، اخر شاخص

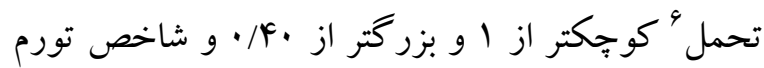

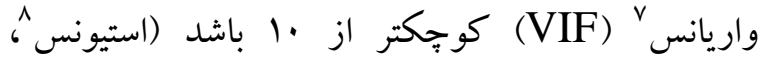

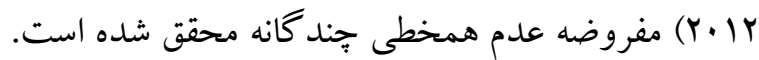
نتايج نشان داد كه ضرايب تحمل متغيرهاى بيش بين از

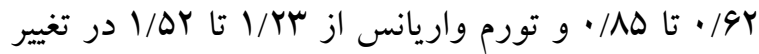
هستند. بر اين اساس مى توان رأى به تحقق مفروضه داد. در بررسى مفروضه استقلال خطاها از آماره دوربين واتسون استفاده شد. ضر ايب نزديكك به ب براى اين آماره نشان از استقلال خطاها دارند(نتر، كاتنر، ناتشهيم و

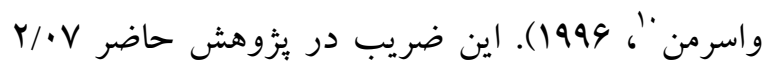
بود. نتايج محاسبه همبستگى كانونى ادراكات والدينى و بهزيستى روانشناختى و اجتماعى در جدول r آورده شده

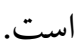

- Tolerance

7. Variance inflation facto(VIF)

${ }^{8}$ - Stevens

9 - Durbin-Watson

${ }^{10}$ - Neter, Kutner, Nachtsheim, \& Wasserman
نتايج جدول ا نشان مىدهد كه ميان ادار كات والدينى با بهزيستى روانشناختى و اجتماعى روابط مثبت و معنادارى

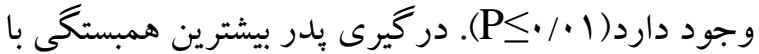
بهزيستى روانشناختى و اجتماعى را داراست. در ادامه مفروضات نرمال بودن تكك متغيره و جند متغيره توزيع متغيرها، عدم همخطى جند كانه' و استقلال خطاها بررسى شد. نتايج جدول ا نشان داد كه با در نظر گرفتن

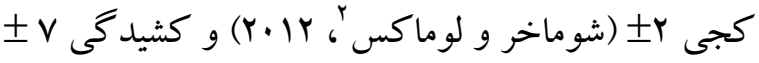
(وست، فينج و كوران"، (1990)، نرمال بودن تكك متغيره براى تمامى متغيرها محقق شده است. در بررسى نرمال بودن جند متغيره، پֶ از محاسبه مقادير باقيماندههاى

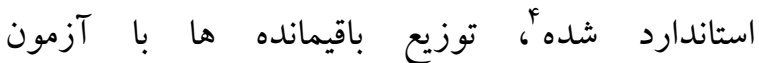

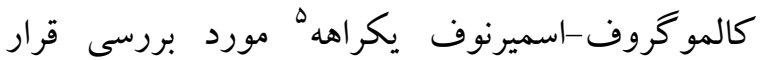
كرفت. بزرگتر بودن سطح معنادارى آزمون از آلفاى نشان از نرمال بودن توزيع متغيرها دارد(ميرز و P همكاران، 19 (Y). نتايج نشان داد كه توزيع باقيماندهها

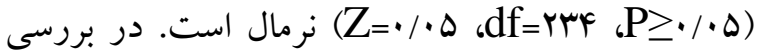

\footnotetext{
1- Multicollinearity

2- Schumaker \& Lomax

3 - West, Finch, \& Curran

4- Standardized residuals

5 - One way Kolmogorov-smirnov
} 


\begin{tabular}{|c|c|c|c|c|c|c|c|}
\hline سطح معنادارى & df & $\mathbf{F}$ & لامبداى ويلكز & مجذور همبستغى & همبستكى كانونى & مقادير ويزه & توابع كانونى \\
\hline.$/ \ldots 1$ & ir & $\Lambda / \wedge \vee$ & .194 & $\cdot / \mu F$ & $\cdot / \Delta \Lambda$ &.$/ 01$ & 1 \\
\hline$\cdot / V 9$ & $\Delta$ & $\cdot / \Delta r$ & $\cdot / 99$ &.$/ \cdot 1$ &.$/ 11$ &.$/ \cdot 1$ & $r$ \\
\hline
\end{tabular}

جدول Y نشان مىدهد كه همبستگى ميان متغيرهاى ادراكات والدينى، FF درصد از تغييرات متغير كانونى بهزيستى قابل ييش بينى است. وزن و بار كانونى در توابع. كانونى ادراكات والدينى و بهزيستى برابر با هـه • • است. كانونى ادراكات والدينى و بهزيستى در جدول ب آورده مجذور همبستخى ( مFF/•) نشان مىدهد كه واريانس

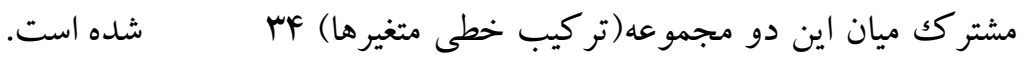
درصد است. بدين معنى كه با آكاهى از متغير كانونى

جدول r وزن و بار كانونى اجزا در توابع ادار كات والدينى و بهزيستى

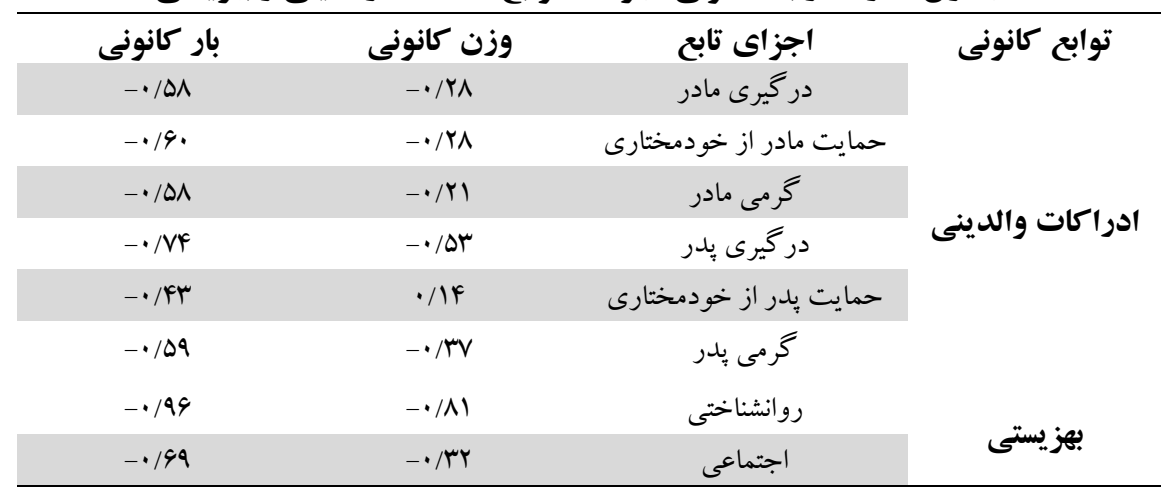

واحد كاهش در در گيرى بِدر ميزان همبستخى دو تابع به

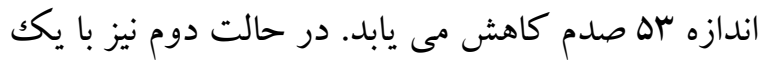
واحد كاهش در بهزيستى روانشناختى ميزان همبستگى 1 صدم كاهش مى يابد. بارهاى كانونى نشان مىدهند كه در تشكيل متغير كانونى ادراكات والدينى، بيشترين سهم مربوط به درگيرى بدر(VF)

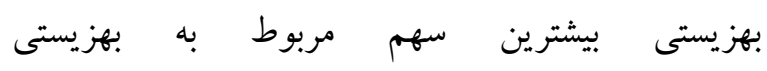
روانشناختى(94/.-) است. تلخيص يافتها در شكل 1 آورده شده است.
وزن هاى كانونى نشان دهنده سهم نسبى هر يكك از متغيرهاى اصلى در ميزان همبستخى كانونى و بارهاى كانونى نشان دهنده سهم هر متغير اصلى در تشكيل متغير كانونى است(يوسفى و همكاران، سوسا). نتايج جدول r نشان مىدهد كه در تابع ادراكات والدينى، درگيرى

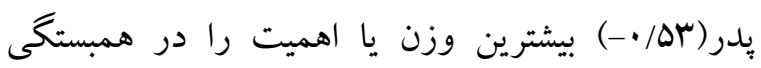
كانونى داشته است. در تابع بهزيستى نيز بهزيستى روانشناختى داراى بيشترين وزن است( اN/ •-). در حالت اول با فرض ثابت نكه داشته شدن ساير متغيرها، با يكك 


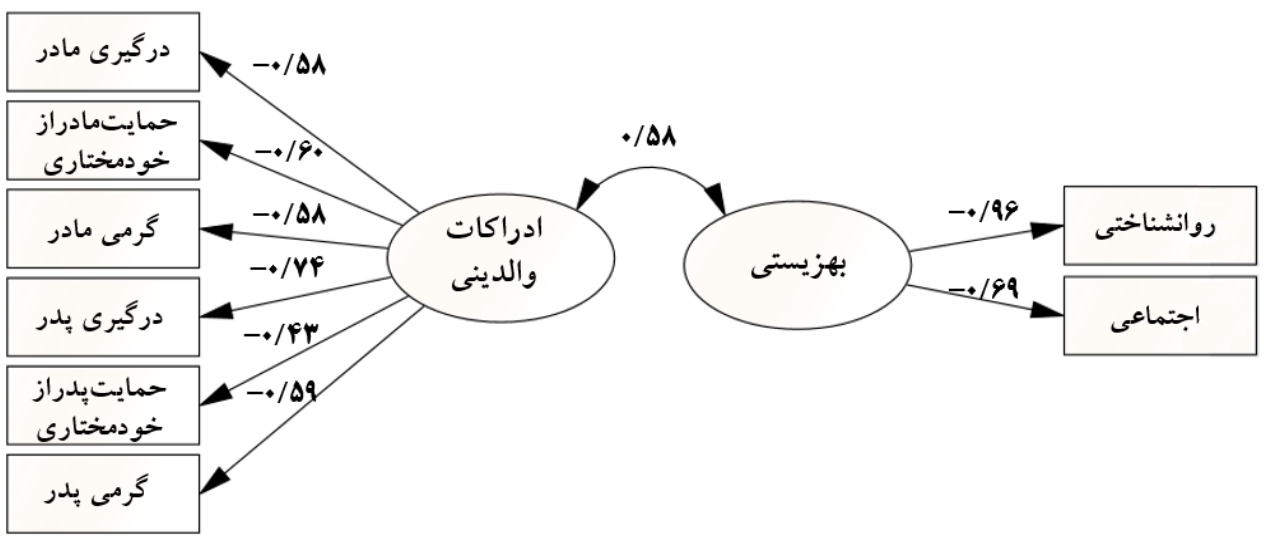

شكل ا مدل كانونى روابط ميان ادراكات والدينى و بهزيستى

مردان در زندگى خانوادگى برسشهاى گوناگونى رادر زمينه تأثيرات مثبت و مخرب بدران بر زندگى فرزندان برانخيخته است. نتيجه اين پبرسشها شواهد روزافزون مبنى بر اهميت ويزه تأثير رفتارهاى يدران بر بهبودى و

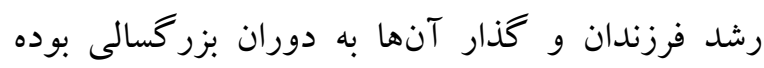
است. علاوه بر اين بدر به عنوان منبع حمايتى مادر، بر سلامت روان مادر و در نتيجه بهطور غيرمستقيم بر سلامت روانى فرزند تأثير بارزى دارد. حضور بدر و ياسخگ

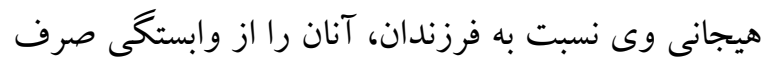
به حالات هيجانى مادر رها ساخته و زمينه استقلال و خودمختارى را فراهم مى آورد (يلانتين، اوكويالا و نى'

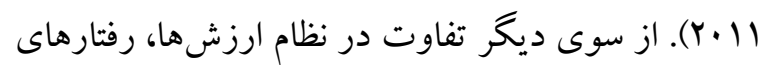

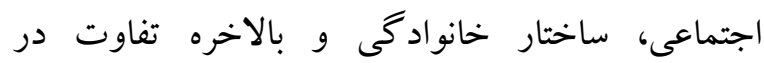
تعاملات خاص خانواده در كشور ما مى تواند تبيين كننده نقش بيشتر بدر در بهزيستى فرزندان باشد؛ در فرهنكى كه

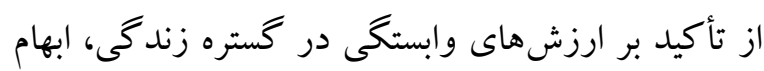
نقش زوجين در خانواده و برزخ بين بدرسالارى و

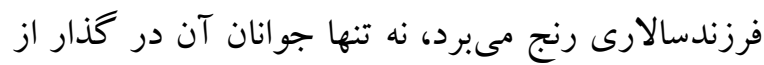
وابستكى به استقلال با مشكلاتى مواجه مىشوند بلكه

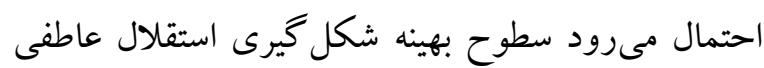

\footnotetext{
'- Plantin, Olykoya \& Ny
} يزٔوهش حاضر با هدف بررسى روابط ميان ادراكات و الدينى با بهزيستى روان شناختى و اجتماعى با استفاده از تحليل همبستكى كانونى انجام شد. نتايج نشان داد كه ميان درگيرى، حمايت از خودمختارى و گرمى بدر و و مادر با بهزيستى روانشناختى و اجتماعى در دانشجويان روابط مثبت و معنادارى وجود دارد. ساير نتايج نشان داد كه با آكاهى از متغير كانونى ادراكات والدينى، مى توان r M درصد از تغييرات متغير كانونى بهزيستى را بيش بينى كرد. در تابع ادراكات والدينى، دركيرى يدر و در تابع بهزيستى نيز بهزيستى اجتماعى داراى بيشترين وزن بودند.

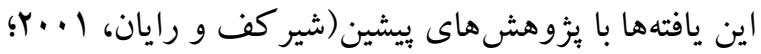

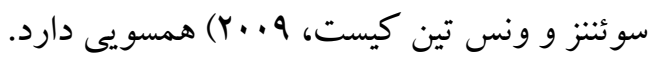

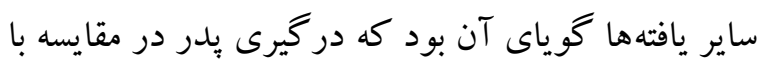
ادراكات مادر سهم بيشترى در ارتباط متغيرهاى كانونى دارد. به نظر مىرسد هر جند به طور سنتى، مادران داراى نقش بيشترى در فرزنديرورى انگاشته مىشوند، اما اهميت بدران در فرزنديرورى و مسائل روانشناختى فرزندان، در حال حاضر جهرهى ديخرى بيدا كرده است. از سوى ديخر تغييرات اجتماعى از قبيل ورود زنان و ترون مادران به عرصههاى شغلى و اجتماعى و افزايش حضور 
سلامت روانى و ساز گارى فرزندان خود محافظت كنند

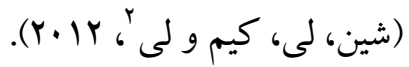

در مجموع بر اساس نظريه خود تعيين گرى (رايان و

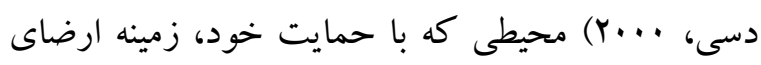
نياز به خودمختارى يا داشتن حق انتخاب و تصميم كيرى حداقل در زمينه مسائل شخصى رادر افراد فراهم نمايد با افزايش تمايل انگيزش درونى، به سلامت و بهزيستى روانشناختى افراد يارى مىرساند. علاوه بر آن گرولنيك لـك و همكاران(199V) بر اين باورند كه افراد نياز دارند به

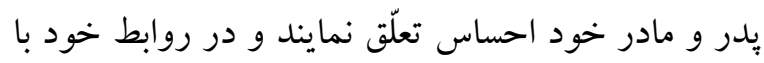
آنان احساس امنيت كنند. بر اين اساس بدران و مادرانى كه به نيازهاى فرزندان خود حسّاس بوده و رفتار كرم و صميمى تو أم با تشويق نسبت به آنان داشته باشند، با ايجاد امنيت خاطر، نياز به تعلّق را در آنان ارضاء خواهند كرد كه اين به نوبه خود سطوح بالايى از بهزيستى روان شناختى و اجتماعى را در آنان موجب گردد.

\section{نتيجه كيرى}

بر اساس يافتهاى بزّوهش حاضر و مبانى نظرى، به نظر مىرسد والدينى كه به فرزندان خود اجازه مىدهند تا در مورد مسائلى كه مستقيماً به آنان مربوط است به صورت

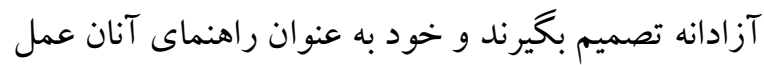
مى كنند و علاوه بر آن در تصميمات مشتركى كه در خانواده وجود دارد آنان را شركت مىدهند، نياز به خودمختارى رادر آنان تسهيل نموده و زمينه تلاش براى كمال و تحقق نيروهاى بالقوه فردى و افزايش كيفيت در روابط بين فردى در محيط خانوادگى، تحصيلى و

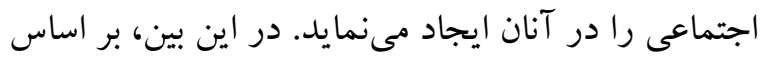
نتايج يزوهش حاضر، بدر نقش بررنگك ترى در اين زمينه
در آنها نيز متفاوت باشد. بنابراين در جنين شرايطى و با توجه به اينكه تعارضات بدر-فرزندى، به ويزه در دوران نوجوانى و پس از آن خيلى بيشتر از تعارضات مادر-

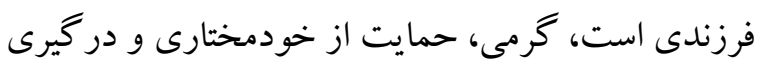
بدر مىتواند اثرات مثبتى بر بهزيستى فرزندان داشته

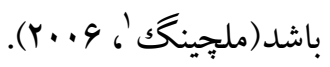

يافته هاى يزٔوهش حاضر در هماهنكى با نظريه خودتعيين - باسنين

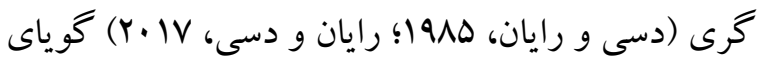
آن است كه گرمى، حمايت از خودمختارى و درگيرى والدين بر ابعاد انكيزشى، شناختى و رفتارى اثر مى كذارد.

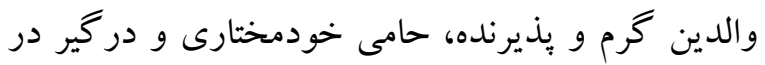

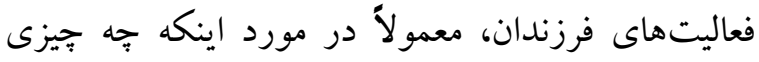
بايد انجام شود، اطلاعات كافى و مناسبى در اختيار فرزندانشان قرار مىدهند و وظايف مورد نظر كاملاً مشخص هستند. به همين دليل فرزندانشان تكاليف و وظايف خود را به خوبى مىدانند، منطقى هستند و در انجام وظايف انعطافيذيرند. جنين والدينى ناساز گارىهاى فرزندان را مستقيماً حل مى كنند و و انتظارات خاصى از رفتار فرزندانشان دارند. به عبارت ديخر، حمايت والدينى يكك منبع اصلى حمايت اجتماعى براى دانشجويانى است كه در معرض جالشهاى روزمره زندگى و به ويزه جالشهاى تحصيلى قرار دارند و در نتيجه ادراكك از ارتباط بهينه با والدين با افزايش احساس وتره

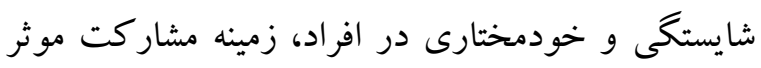
در اين جالشها را فراهم مى كند. والدين توانمندتر كه سطوح بالايى از مراقبت والدينى و سطوح بايينى از بيش -

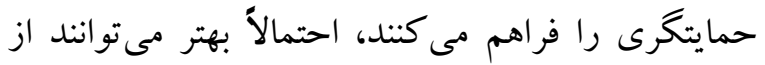


نيازهاى بنيادين روانشناختى، خود كار آمدى و شخصيت كه در ساير مطالعات در ارتباط با متغيرهاى بثزوهش حاضر مورد بررسى قرار گرفته بودند، لحاظ نشده است. به نظر مىرسد روابط ميان ادراكات والدينى با بهزيستى روانشناختى و اجتماعى به واسطه متغيرهاى ديخرى

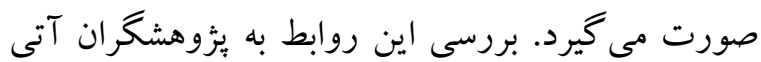
بيشنهاد مىشود.

سياسگز ارى

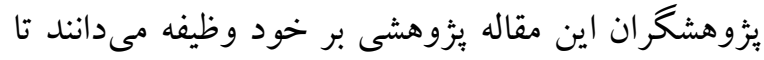
از تمامى همكارانى كه در اين ئزوهش ما را يارى رساندند كمال تقدير و تشكر را داشته باشيم.

\section{References}

Asghari Ebrahimabad M, \& Mamizade M. (2018). An Investigation into the Role of Psychological Fexibility and Hardiness in Explaining Soldiers' Psychological Well-Being. Research in Clinical Psychology and Counseling, 8(1), 37-51(in Persian).

Barwais F. (2011). Definitions of Wellbeing, Quality of life and Wellness. Brisbane: National Wellness Institute of Australia.

Chirkov VI, \& Ryan R. (2001). Parent and teacher autonomy support in Russian and US. Adolescents: Common effort and academic motivation. Joumal of Cross-Cultural Psychology, 2(5), 618-635.

Cohen J. (1992). A power primer. Psychological bulletin, 112(1), 155-159.

Cordeiro PMG, Paixão MP, Lens W, Lacante M, \& Luyckx K. (2018). Parenting styles, identity development, and adjustment in career transitions: The mediating role of psychological needs. Joumal of Career Development, 45(1), 83-97.

Deci EL, \& Ryan RM. (1985). The general causality orientations scale: Self-determination in
دارد. اين امر به ويزه در مورد دانشجويان كه از محيط

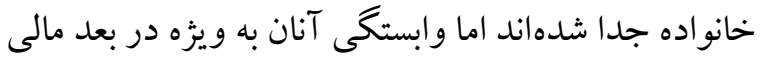
و سر و سامان دهى به مسائلى از قبيل اسكان، رفت و آمد به محل تحصيل و... همجّنان وجود دارد، صادق است. از سوى ديخر روابط گرم و صميمانه بِر و مادر با فرزندان،

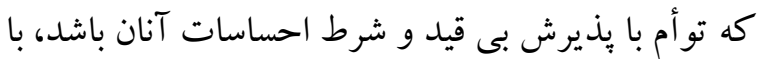
ايجاد احساس تعلّق، دلبستكى و امنيت خاطر، زمينه ايجاد نغرش مثبت نسبت به خود، داشتن هدف در زندگى، يذيرا بودن نسبت به تجربيات جديد و برقرارى روابط كرم، رضايت بخش و صميمانه با ديكران از يكك سو و ديد مثبت نسبت به ذات انسان و اعتماد منطقى به ديخران، احساس تعلّق نسبت به جامعه و عضو مهمى از آن بودن و اميدوارى نسبت به جامعه و آينده آن رادر فرزندان ايجاد مىنمايد. جنين نخرشهايى به نوبه خود اثرات نسبتاً پايدارى بر سلامت روانى فرزندان در سنين مختلف بر

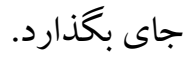

يافتهاى اين بُزوهش تلويحات كاربردى مهمى دارد. نتايج اين ئزوهش نشان داد كه ادراك از سبككهاى فرزنديرورى بر بهزيستى روانشناختى دانشجويان اثر دارد. بنابراين فراهم كردن محيطى خانوادگى كه در آن والدين فرزندانشان را حمايت كنند، با برقرارى روابط كرم و صميمى از آنها مراقبت كنند و انتظاراتشان متناسب با توانمندىهاى فرزندانان باشد به ارتقاى سلامت روانى فرزندان كمكك مى كند. يثزوهش حاضر به واسطه استفاده از ابزار خود كزارشى و رونى

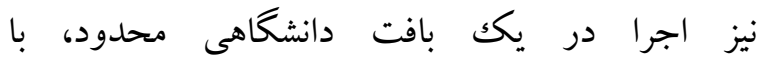
محدوديتهايى براى تعميم يافتهها به ساير دانشجويان و نيز ساير بافتهاى فرهنگى روبرو است. علاوه بر آن در يُزوهش حاضر نقش مداخله كر ساير متغيرها از قبيل 
personality. Joumal of research in personality, 19(2), 109-134.

Dickerson S. (2018). Psychological Well-being and Health Gains in the Developing World: Evidence from Peru and Malawi (Doctoral dissertation). University of Maryland.

Faraji E, Moghtader L, \& Asadi Majareh S. (2019). The relationship between social support and the personality traits of Extroversion and Neuroticism and psychological well-being in women with chronic pain. Journal of Anesthesiology and Pain, 9(4), 29-40 (in Persian).

Gagné M. (2003).The role of autonomy support and autonomy orientation in prosocial behavior engagement. Motivation and emotion, 27(3), 199-223.

Grolnick W, Deci EL, \& Ryan R. (1997) Intemalization within the family: The self-determination theory. In Gruse JE. \& Kaczynski L. Parenting and children $\mathrm{s}$ internalization of values: A handbook of contemporary theory (PP. 135 161). New York: Willey Press.

Grolnick WS. (2009). The role of parents in facilitating autonomous self-regulation for education. School Field, 7(2), 164-173.

Hamidi F, \& Ansari S. (2017). The Relationship between Parenting Styles, Students' Psychological Wellbeing and Hardiness. Journal of Family and Research, 13(32), 47-66 (in Persian).

Hardoon DR, Szedmak S, \& Shawe-Taylor J. (2004). Canonical correlation analysis: An overview with application to learning methods. Neural computation, 16(12), 2639-2664.

He YM, Liu T, \& Chen YW. (2017).Influence of parental rearing pattems on academic bumout: The mediating role of psychological capital and self-control. In Industrial Engineering and Engineering Management (IEEM), 2017 IEEE International Conference on (pp. 23072311). IEEE.

Joshanloo M, Rostami R, \& Nosratabadi M. (2006). Examining the factor structure of the Keyes' comprehensive scale of well-being. Joumal of Iranian Psychologists, 9, 35-51(in Persian).
Joussemet M, Landry R, \& Koestner R. (2008). A selfdetermination theory perspective on parenting. Canadian Psychology/Psychologie canadienne, 49(3), 194-200.

Keyes CL. (2005). Mental illness and/or mental health? Investigating axioms of the complete state model of health. Joumal of consulting and clinical psychology, 73(3), 539-548.

Keyes CLM. (1998). Social well-being. Social psychology quarterly, 61, 121-140.

Kim K, \& Rohner RP. (2002). Parental Warmth, control, and involvement are schooling predicting academic achievement among Korean American adolescents. Journal of Cross-Cultural Psychology, 33(2), 127- 140.

Lu M, Walsh K, White S, \& Shield P. (2017). The associations between perceived maternal psychological control and academic performance and academic self-concept in Chinese adolescents: The mediating role of basic psychological needs. Journal of Child and Family Studies, 26(5), 1285-1297.

Melching JA. (2006). Exploring Parent-Adolescent Conflict: An Examination Comelates and Longitudinal Predictors in Early Adolescence. Thesis Master of Science in Psychology, University of New Orleans.

Meyers LS, Gamst G, \& Guarino AJ. (2016). Applied multivariate research: Design and interpretation. Sage publications.

Neter J, Kutner MH, Nachtsheim CJ, \& Wasserman W. (1996). Applied linear statistical models (Vol.4, p. 318). Chicago: Irwin.

Nie Y, Chua BL, Yeung AS, Ryan RM, \& Chan WY. (2015). The importance of autonomy support and the mediating role of work motivation for well-being: Testing self-determination theory in a Chinese work organization. Intemational Joumal of Psychology, 50(4), 245-255.

Plantin L, Olykoya A, \& Ny P. (2011). Positive health outcomes of fathers' involvement in pregnancy and childbirth patemal support: a scope study literature review. Fathering, 9(1), 87-102.

Robbins RJ. (1994). An assessment of perceptions of parental autonomy support and control: Child 
and parent correlates. Unpublished Doctoral Dissertation, Department of Psychology, University of Rochester.USA.

Ryan RM, \& Deci El. (2000). Self -determination theory and facilitation of intrinsic motivation, social development, and well- being. American psychologist, 55, 68- 78.

Ryan RM, \& Deci EL. (2016). Facilitating and hindering motivation, leaming, and well-being in schools: Research and observations from self-determination theory. Handbook on motivation at schools, 96-119.

Ryan RM, \& Deci EL. (2017). Self-determination theory: Basic psychological needs in motivation, development, and wellness. Guilford Publications.

Ryan RM, Huta V, \& Deci EL. (2008). Living well: A self-determination theory perspective on Eudaimonia. Joumal of happiness studies, 9(1), 139-170.

Ryan RM. (2009). Self-determination theory and wellbeing. Social Psychology, 84, 822-848.

Ryff CD, \& Singer B. (1998). The contours of positive human health. Psychological inquiry, 9(1), 128.

Ryff CD. (1989). Happiness is everything, or is it? Explorations on the meaning of psychological well-being. Joumal of personality and social psychology, 57(6), 1069.

Saffarinia M, Tadris Tabrizi M, Mohtashami T, Hassanzadeh P. (2014). The Effect of prosocial personality and Narcissism on Social Well-being of the Residents in Tehran City. Knowledge \& Research in Applied Psychology, 15(3), 35-44 (in Persian).

Schumacker RE, \& Lomax RG. (2012). A beginner's guide to structural equation modeling. Routledge.

Sharbatiyan MH, \& Erfanian Ghasab E. (2018). The Influence of Social Capital on Social WellBeing through the Mediating Role of Quality of Life and Satisfaction with Life (Case Study: 18-30 Year Old Youth in Ghaen). Social Development, 13(1), 195-227 (in Persian).

Shin H, Lee J, Kim B, \& Lee SM. (2012).Students' perceptions of parental bonding styles and their academic bumout. Asia Pacific Education Review, 13(3), 509-517.

Soenens B, Vansteenkiste M, \& Sierens E. (2009). How Are Parental Psychological Control and Autonomy-Support Related? A ClusterAnalytic Approach. Joumal of Marriage and Family, 71,187-202.

Stevens JP. (2012). Applied multivariate statistics for the social sciences. Routledge.

Strümpfer DJW. (1990). Salutogenesis: A new paradigm. South African Joumal of Psychology, 20(4), 265-276.

Tanhaye Reshvanloo F, \& Hejazi E. (2010). The Relationships among the Perceived Parenting Styles, Academic Motivation and Academic Achievement in High School Students. Training and Leaming Researches, 1 (39), 114 (in Persian).

Tanhaye Reshvanloo F, \& Hejazi E. (2011). Matemal and paternal involvement, autonomy support and warmth: predictors of adolescence selfesteem. Intemational Joumal of Behavioral Sciences, 5(4), 343-350 (in Persian).

Tanhaye Reshvanloo F, \& Hejazi E. (2012). The Role of Matemal and Paternal Involvement, Autonomy Support and Warmth on Adolescents Self-Determined Motivation and Academic Achievement. Joumal of Family Research, 8(1), 67-82 (in Persian).

Tanhaye Reshvanloo F, \& Hejazi E. (2014). Perceived parenting styles, academic achievement and academic motivation: A causal model. Intemational Joumal of Education and Applied Sciences, 1(2), 94-100.

Tanhaye ReshvanlooF, \& Talepasand S. (2018). Factor Structure and Psychometric Properties of Perceptions of Parents Scale (POPS) in High school students. Journal of Rooyesh-eRavanshenasi, 7 (9), 265-290(in Persian).

Thurber A, Bohmann CR, \& Heflinger CA. (2018). Spatially integrated and socially segregated: The effects of mixed-income neighbourhoods on social well-being. Urban Studies, 55(9), 1859-1874.

Torkamani M, Gharaee A, Sheykhani F, \& Tanhaye Reshvanloo F. (2018). Structural relationships 
100 همبستخى كانونى ادراكات والدينى با بهزيستى روانشناختى و اجتماعى در دانشجويان

between Matemal and Patemal Warmth with Hope in Girl Students. Joumal of Sociology of Education, 9, 1-11 (in Persian).

Van der Kaap-Deeder J, Vansteenkiste M, Soenens B, \& Mabbe E. (2017). Children's daily wellbeing: The role of mothers', teachers', and siblings' autonomy support and psychological control. Developmental psychology, 53(2), 237-251.

Villarosa JB, \& Ganotice FA. (2018). Construct validation of Ryff's psychological well-being scale: Evidence from Filipino teachers in the
Philippines. Philippine Journal of Psychology, 51(1), 1-20.

West SG, Finch JF, \& Curran PJ. (1995). Structural equation models with non-normal variables: Problems and remedies, In RH. Hoyle (Ed.), Structural equation modeling: Concepts, issues and ...56-75), Sage, Thousand Oaks, 1995.

Yousofi A, Bagheriyan A, \& Shojaee M. (2015). The Logic and Use of Canonical Correlation Analysis in Social Researches. Joumal of Social Sciences, 11(2), 207-233 (in Persian). 